\title{
SZEMPONTOK AZ IRÁNYÍTÁSI RENDSZER MODELLVÁLTÁSÁHOZ
}

\author{
FARAGÓ LÁSZLÓ
}

A békés rendszerváltás hatására a korábbi hatalmi struktúrához kötổdố központi irányítási rendszer felbomlik, intézményi rendszerének szétzúzása folyamatban van. Az emberek, a politikai pártok többsége modern, szociális piacgazdaság kiépítését tartja kívánatosnak, s ezt gyakran a jóléti állam ideájához kötik.

Ma, amikor vigyázó szemünket a fejlett Nyugat-Európára vetjük, szükségesnek tartom felhívni a figyelmet arra, hogy a fejlett országok korábbi sikermodellje sok hasonlóságot mutat(ott) a mi levetni kívánt gyakorlatunkkal. A szû́k hatalmi csoport önös érdekeinek alárendelt, centralizált fejlesztési politikánk igazi alternatívája nem biztos, hogy a fejlett országok korábbi modernizációs folyamatának adaptálása. Valószínư, hogy a fejlett országokban napjainkban körvonalazódó decentralizált irányítási és gazdaságfejlesztési gyakorlatot kellene meghonosítani. Vagyis meg kellene kísérelni együtt lépni a nálunk fejlettebb országokkal.

A tốkés országok fejlôdési tendenciája a hetvenes évek végéig az állami irányítás, a centralizáció, a tervezés erôsödését eredményezte, ami több országban (Svédország, NSZK stb.) közigazgatási centralizáciỏhoz is vezetett. A hetvenes évek végére a szociál-liberalizmus értékteremtő ereje gyengült, az etatizmus, a szociáldemokrácia válságba került, s egy liberálisabb gazdaságpolitikának és konzervatívabb értékrendnek adta át a helyét. A gazdasági demokrácia megvalosulását már nem a további központosításban, államosításokban látják, hanem a munkavállalói tulajdon kiterjesztésében és a kis magántulajdon védelmében. Decentralizáció indult meg az élet csaknem minden területén. Ezek a decentralizációs törekvések nem csupán a korábbi rendszer tagadásában, vagy csupán holmi parókializmusban gyökereznek, e tendenciákat objektív gazdasági változásokon kívül az ember területi-kulturális dimenziója, a helyi függőség és a fejlôdésrốl vallott nézeteink felülvizsgálata is alátámasztja.

Az állami beavatkozás mérséklése, a központi irányítás szerepének változása, a tervezés korábbi gyakorlatával való szakítás nem a tervezésben rejlő elổnyökról vagy a szociảlis védôhálóról való lemondást jelenti. A kivánatos piaci folyamatok érvényre juttatása, a hatáskörök és finanszírozási források decentralizációja nemhogy nélkülözhetốvé teszi a tervezést, hanem csak most válik igazán lehetớvé és szükségessé, hogy vállalati, regionális és helyi kormányzati szinten valóságos tervezôi munka bontakozhasson ki. Nem a jóléti célokat kell elvetni, hanem a megvalósítás más módjait kell megkeresni. A korábbi ágazati irányítási rendszer helyett egy tércentrikus modell bevezetését tartom helyesnek.

\section{Az irányított típusú modern tókés gazdasági rendszer}

A szocialista országokra is javarészben jellemzô hazai gyakorlat bemutatása és kritikája nem szükséges. Ezért a summás megállapítások minden ódiumával a fejlett országok gyakorlatának 
néhány olyan jellemzôjére hívom fel a figyelmet, amelyet e dolgozat témája szempontjából fontosnak tartok.

A nagy gazdasági válság, majd a második világháború hatására a kapitalista országokban is bổvült a központi állami funkciók köre, erốsödött a központi itányítás, átfogó gazdaságtervezés és -szabályozás irányába tettek lépéseket. A tervezés a központi célok megvalósításának, a piaci folyamatokba való direkt beavatkozásnak bürokratikus eszközévé vált.

A második világháborút követổ idôszzakban a keynesi válságellenes politika helyébe egyre inkább egy átfogó, hosszútávú stratégiára és szabályozásra épülỏ központi irányítás lépett (Franciország, Hollandia, Japán, Norvégia, Svédország stb.). A jóléti állam megkísérelte a liberális kapitalizmust gazdaságilag hatékonyabbá és társadalmilag igazságosabbá tenni. Egyre növekvổ réteget kellett ellátni a fogyasztási cikkek mind jobban bővülõ körével, így a tervezés középpontjába a gazdasági növekedést kellett állítani. Uralkodó nézet volt, hogy földrajzi elhelyezkedéstốl, gazdasági fejlettségtôl, tradícióktól függetlenül, központi kormányzati segítséggel egy új ipari társadalmi rendet kell mindenütt kiépíteni. A hagyományos piaci szféra mellett kialakult egy tervezett gazdasági szféra, melyet az állami tisztviselốkkel, politikusokkal szoros kapcsolatban lévổ technokraták vezettek. Az irányított piac óriási termelỏ szervezeteket kívánt meg, és ezekben lehetôvé vált a hatékony tervezés. Az élet csaknem minden területén az egységesítés volt a jellemzổ. A kiskereskedelemben, a vendéglátásban, a szolgáltatásokban elterjedtek az üzlethálózatok. A településfejlesztésben, az építészetben a helyi, nemzeti sajátosságoktól független trendek domináltak. Az állam és az óriásvállalatok , átvállalták” az egyénekrốl, a kis közösségekrôl való gondoskodást. A fejlet Nyugat ,,felvállalta” a harmadik világról való gondoskodást, ami segítségével fent kívánta tartani a centrum-periféria viszonyt. ${ }^{1}$ (A szocialista országok törekvései - hogy saját képükre alakítsák a fejlôdố országokat - kevesebb sikerrel jártak.)

Az így kialakuló irányítási modell megkísérelte összehangolni a tulajdonviszonyokból fakadó vállakozói szabadságot és a nemzetgazdaság versenyképességét biztosító központi bevatkozást. A kormányprogramok középpontjában a nemzeti szintû gazdasági növekedés állt. Az ebból eredố fejlettségbeli különbségek erôsödésével a kormányzatok számára politikai kérdéssé vált a fejlổésben elmaradó térségek segítése. A gazdasági fellendülés megteremtette a szükséges anyagi feltételeket egy központi területi támogatási politika megvalósításához. Szinte minden fejlett országban sor került a gazdaságilag elmaradott területek központi segítséggel való fejlesztésére. A 60-as években a virágkorát élố regional science, a területi politika és a területi tervezés is e központi politikához nyújtott segítséget. Még a decentralizációt hangoztató törekvések, mint például a növekedési pólus elmélet, gyakorlati megvalósítása is egy felülrôl kezdeményezett program volt, amelynek elsődleges célja a gazdasági növekedés területi kiterjesztése, a központi régiókra nehezülô nyomás mérséklése.

E modell néhány további jellemzóje:

a) A rendszer a gazdaság alapelemeiból épül fel. A területi megközelítésekben is, a neoklaszszikus , ,képletnek” megfelelôen a munkaerổbốl és a tôkébốl (vállalatokból) kell kiindulni. A , ,tôke” logikája a legfốbb rendezó elv. A területi érdekek figyelembe vételére nincs mód, mert az rontaná a gazdasági hatékonyságot. Az állami beavatkozás is elsốsorban a piac elégtelen mứködését hivatott korrigálni, a gazdasági növekedés elôtt álló korlátokat kell felszámonia. E modell feltételezi, hogy a nagy monopóliumok, részvénytársaságok érdekei egybeesnek a 
nemzet érdekeivel. Az egyéneknek, a kisközösségeknek, a helyi társadalmaknak is ebbe a nagy hatékony gépezetbe kell integrálódniuk.

b) Az állami beavatkozás szükségessége általánosan elfogadott doktrína. Szükség van egy régión felüli/kívüli szereplổre, aki a nemzet távlati érdekeit próbálja meg artikulálni, illetve az elsổ tételbốl eredố feszültségeket enyhíti. A paternalista jóléti állam a redisztribució segítségével alanyi jogon biztosítja minden állampolgár számára a megélhetés minimális szintjét. $\mathrm{Az}$ állam, a központi irányítás további feladata a területi igazságosság (equity) biztosítása. A gazdálkodó egységeknek saját parciális hatékonysági kritériumaiknak kell megfelelniük, és az állam hivatott az ebbôl eredô feszültségek enyhítésére, a területi igazságosság követelményének érvényesítésére.

c) A legrelevánsabb tervezési szint a nemzetgazdaság. A régiók, a települések, illetve az ezekben élố közösségek csak alrendszerek, melyeknek legföbb feladata a nemzeti célokhoz való hozzájárulás. A tervezési egységek, a rẻgiók, a települések is e mechanizmus végrehajtási eszközei és nem a célokat is alakító aktív részesei. A településhálózat hierarchikus képe illeszkedik e gondolati struktúrába. A kis települések hatékony irányítása/tervezése és ellátása nem megoldható, ezért célszerû ezeket összevonni. ${ }^{2}$

A 70-es évektôl a helyzet megváltozott. Az állami redisztribúció további kiterjesztésében már csak a szubvencióra szoruló válságágazatok és az e rendszerbôl hasznot húzó bürokrácia érdekelt. A társadalom többségét alkotó középrétegen belüli újraelosztás feleslegessé válik. Az új technológiák, iparágak megjelenése, a régiek eltúnése, a dinamikus iparágak területi elhelyezkedésének megváltozott körülményei hatással voltak a hatékony termelés feltételeire, újra felborították a területi egyensúlyt. Minden igyekezet ellenére, e modell gyakorlati megvalósulása erôsen hierarchizált teret hozott létre. A termelốerôk fejlettsége és fejlôdési iránya ma már lehetổvé tenné, hogy a legfejlettebb országokban a térbeli hierarchia jelenlegi formaii megszúnjenek. ${ }^{3}$

A hatalmi multinacionális cégek folytatják a piacok további integrálását, amelyek egymás felvásárlásával tovább növelték erejüket. A területi, sốt a nemzeti ráhatás is szinte lehetetlenné vált. A nemzetközi tôke érzéketlen az egészen kis piacokra, a helyi társadalmak sajátos bajaira és lehetổségeire.

Ezzel a tendenciával párhuzamosan a decentralizáltabb, kisebb szervezetek hatékonysága növekedett, lehetôség kínálkozott a jobb alkalmazkodóképességükben rejlổ lehetôségek kihasználására. A legfejlettebb országok kormányai neoliberális politikát kezdtek folytatni, a területi politika és a területi tervezés a kínálati közgazdaságtan áldozatává válik. A kỏzponti erôforrásallokáció, így a központi tervezés is, fokozatosan veszít a jelentőségéból. A laissez-faire politikában a kissé elbürokratizálodott tervezés vál ságba került. A kevésbé hatékony központi megoldások helyett sok regionális és helyi kezdeményezés igyekezett a területi egyensúlyi állapotokat javítani.

A 80-as évektól egyre gyakrabban találkozhatunk az ipari társadalom, a jóléti állam elutasításával. E mögött két irányzat húzódik meg. Az egyik a már megszerzett anyagi javak örömtelenségében, az anarchizmus szellemi tradícióiban és az alternatív kultúrákban gyökerezik. A másik a hagyományos polgári értékek újraéledésben: a család, a területi, vallási, kulturális közösségek értékeinek és a közvetlen tulajdonosi érdekeltségben rejlô elônyöknek az újrafelfedezésében. Ez utóbbinak van nagyobb jelentôsége, hiszen ez egybeesik az új ipari forradalom 
igényeivel. Az új gazdasági liberalizmus, amelyben a vállalkozás, a magántulajdon újra nagy szerepet kap, erkölcsi, politikai konzervatívizmussal párosul. Az egyének, a kis közösségek úgy lehetnek szabadok, ha a tradícionális értékekkel körülbástyázzák magukat.

A kelet-európai országok csaknem mindegyikében elutasítják a korábbi uniformizált, totalitárius rendszert. Az utópista szocialista ígéretekben csalódott nemzetek egyrészt a korábbi rendszer tagadására, másrészt saját identitásuk keresésére építik megújuló politikájukat. Szerencsés lenne, ha nem a történelembốl már ismert ,,minden tagadása” lenne az uralkodó tendencia, hanem a nemzetközi tendenciákból és saját történelmünkbôl tanulva próbálnánk megfelelni korunknak.

A kérdés kézenfekvổ: szabad-e a korábban jól bevált modernizációt követnünk, amikor az Nyugat-Európában a 80-as évekre válságba került? Amennyiben mai körülményeink hasonlítanak a 30-40 évvel ezelôtti nyugat-európaiakra, és nem objektív mélytörvényszerũségek késztetik változtatásra a nyugati államokat, akkor akár igent is mondhatnánk. De a társadalmi-gazdasági életben olyan értékek törnek a felszínre, olyan tendenciák erôsödnek meg, amelyek azt látszanak igazolni, hogy sok más kevésbé fejlett országgal együtt másfajta gyakorlatot kellene megvalósítanunk.

A nemzetközi munkamegosztásban bekövetkezett arányeltolódásoknak, a foglalkoztatási szerkezet változási irányának, az ipari termelésben bekövetkezett változásoknak széles irodalma van. A következôkben ezt a sort szeretném kiegészíteni néhány olyan szemponttal, amelyek igazolják a decentralizációs törekvések szükségességét, és rámutatnak arra, hogy másról van szó, mint a fundamentalista parókializmus erôsödésérōl.

\section{Az ember területi-kulturális dimenziója}

A 20. századig az antropológia, az emberföldrajz és a politikai gazdaságtan a kultúrával, mint közös nevezôvel egyetlen tudomány részei voltak. Ma a közgazdászok, az antropológusok és a földrajzosok újra nagyobb figyelmet kellene hogy fordítsanak egymásra és az ember kulturális-területi meghatározottságára.

Az emberek térhasználatának a különbségeit a kultúra is meghatározza: Hall (1966) a proxemic ${ }^{4}$ kifejezést használja a kisléptékü terekre mint kulturális jelenségekre, amely a sokszínú területi kapcsolatok és a különbözố társadalmak eltérô térérzékenységét írja le. A proxemic térben az , ,érzéki" kapcsolatok dominálnak, amelyeket a direkt személyes kapcsolatok behatárolnak. Greenbie (1976) folytatva Hall gondolatát a distemic fogalmat alkotta a nagyléptékü területi kapcsolatok leírására, amelyek elsốsorban a kommunikáció segítségével túllépik a kulturális csoportok határait. A distemic tér vertikálisan és funkcionálisan szervezett, tranzkulturális és nagyfokú mobilitást tételez fel. Érvelésünk szempontjából fontos, hogy a distemic nagyléptékủ rendszerek megkívánják a tevékenységek magas fokú szervezettségét, amelyet superior szervezetek, hatóságok irányítanak. A proxemic kisléptékũ rendszerek ezzel szemben (általában) informális önszervezôdések, és saját politikával rendelkeznek (Greenbie 1976, 92.).

A , primitív" társadalmak esetében a különbözô absztrakt terek többé-kevésbé egybeesnek és azonosíthatóak egy meghatározott földrajzi térrel. A fejlôdés, a technikai haladás következtében a különböző térstruktúrák egyre inkább tágulnak és a földrajzi vetületük elszakad a proxemic kisléptékủ terektốl. 
Greenbie (1976) vizsgálatai alapján állítja, hogy az ember, mint társas lény — az állatokhoz hasonlóan - biztonságát térkapcsolatainak középpontjában keresi. Az ember számára a társadalmi-területi szervezổdések három fố típusa a legfontosabb: 1. az individuális tér, 2. az otthon és 3. a szomszédok, a barátok, a hobbi, a szolgáltatások, valamint a munkahely által meghatározott terület. Az egyén és a társadalom biztonságát a kisebb csoportokban, kisléptékũ terekben találhatja meg. Ezért az emberek szempontjából optimális térszervezổdés is valahol ezen a szinten keresendố.

Már több éve körvonalazódik egy új típusú társadalom képe. (A különbözô megközelítéseknek megfelelôen ennek más-más nevet adnak: posztindusztriális társadalom, információs társadalom, technobürokrata társadalom, programozott (tervezett) társadalom stb.) Ebben a társadalomban vállalati vezetôk és hivatalnokok (technokraták és bürokraták) a , hatékonyság és a racionalitás nevében" ellenôrzik és szervezik a társadalom múkködését szinte minden szinten. A hatalom részesei, a gazdaságilag erổsebbek a függô helyzetben levốk kulturális életét, , ,legsajátabb" szokásait is megváltoztatják, saját (gazdasági) érdekeinek megfelelỏen befolyásolják. A gazdasági beavatkozást ,,kulturális fejlesztés” követi. Ez a ,,fejlesztés” gyakran a kulturális és ökológiai örökség elpusztulásával jár, és így a kisebb körzeteket, relatíve fejletlenebb területeket megfosztják a jövốbeni fejlődés, sốt még az önkifejezés puszta lehetôségétôl is. A politikai és gazdasági kontrol után a saját kultúra, nyelv elvesztése a lakosságot véglegesen elidegenedetté és alsóbbrendũvé teszi.

A társadalom valamennyi tagja része különféle kommunikációs kapcsolatokkal rendelkezổ embercsoportoknak, amelyeknek társadalmi, politikai határai vannak és eltérõ a földrajzi elhelyezkedésük. A mindennapi életben általában egy ember két alapvetônek tekinthetô földrajzi téren belül kommunikál. A technikai haladás és az internacionalizálódás objektív tendenciáinak következtében az árukon, a pénzen, a telekommunikáción keresztül kapcsolatba kerülünk egy egyre táguló területi egységgel. Egyre több olyan döntés születik a lokalitáson kívül, amely hat a mindennapi életre. Nincs is egyéni vagy helyi kompetencia, hogy hassunk rájuk. Helyi szinten senki nem is tudja, hogy ki, hol és miért hozza ezeket a döntéseket. Az egyének, a kisebbségek, a hagyományos és az újabb kis közösségek szenvednek életterük kolonizálásától, a külsố függốségtốl. Részükrốl egyre fokozódik az elégedetlenség a külsố meghatározottsággal szemben, mindenki joggal akar résztvenni az életterét érintó döntésekben.

A másik - az elốbbihez képest viszonylag szúkülố - terület, ahol az egyének, kis közösségek közvetlenül, szemtól szembe kommunikálhatnak, mindenkinek esélye van arra, hogy reagáljon, szükség esetén hasson a folyamatokra. Az egyének, a kisebb közösségek minél inkább úgy érzik, hogy , ,elvesznek" az elsốként említett, egyre növekvố, számu kra átláthatatlan világban, annál inkább felismerik a jelentôségét a mindennapi életterüknek. A kulturális identitás, a helyi függőség tudatában az emberek képesek együttmứködni közös helyi célok megvalósításában.

A regionális identitás abban a (helyi) kultúrában gyökerezik, amelyet a régió szereplổi önmaguk alakítanak. Az identitás függ a régión belüli és a régiók közötti kapcsolatoktól, valamint a társadalom egészéhez füzổdô viszonytól. A kulturális identitás történelmi kategória és nem egy változatlan örökség vagy a tradíciók egyszerü halmaza. Olyan belsố dinamikus folyamat, amelyet a társadalom önmaga állandóan alakít, belsô, tudatosan és önként vállalt átalakulások során fejlôdik, elfogad külsô hozzájárulásokat, asszimilálja, vagy ha szükséges transzformálja 
azokat. Ez az azonosság egyre inkább feltétele az egyének, a csoportok és a nemzetek fejlôdésének. A regionális-kulturális identitás a kollektív akarat és cselekvés alapja. Egyre többet találkozunk olyan nyelvi, vallási, kulturális és foglalkozási csoportokkal, amelyek kifejezésre kívánják juttatni egyediségüket és erôsítik belsố szolidaritásukat. A kisebbségek esetében sajátságaik védelme az elsô lépés kreativitásuk, cselekvési képességük visszanyeréséhez.

\section{A helyi függóség}

A helyi függôség azt fejezi ki, hogy bizonyos társadalmi-gazdsági viszonyok egy meghatározott területi egységen belül termelődnek újra és a mindennapi élet szereplối - emberek, intézmények, gazdálkodó egységek stb. - függnek e területileg újratermelt viszonyoktól. A különböző szereplốk területi függôsége eltérô mértékủ. A helyi függôség versus az áttelepülésre való képesség mértéke a szereplớk karakterétốl, tevékenységük jellegétốl, a kibocsájtások és a felhasznált források jellegétôl függ. A vállalkozások esetében igen fontos azok ,fajtája”: nyereség- vagy nem nyereségérdekelt; kis-, közép- vagy nagyléptékú; állami, magán, szövetkezeti vagy közösségi-e a vállalkozás. A mobilitás képességét ugyancsak meghatározza az épített vagyon aránya és a nem mobil eszközök piaca. Általánosságban azt mondhatjuk, hogy a nagyobb helyi fïggés a helyi közösség, a helyi fejlódés számára kedvezóbb. Ugyanakkor sajátos érdekellentét is megfigyelhetô a helyi szereplôk között: mindenkinek érdeke mások kötôdésének fokozása és nem önként vállalt, saját kötốdéseinek lazítása. ${ }^{5}$

\section{Az emberek helyi függósége}

Mindennapi életünk helyhez kötött. A nagy többség számára van kedvelt, megszokott munkahely (iskola), üzlet(ek), templom stb., és természetesen kialakul egy jó vagy rossz napi rutin. A mindennapi élethez szükséges alapinformációk birtokában az emberek kiegyensúlyozottabbak és könnyebben vállalkoznak, kezdeményeznek az élet más területein, így sikeresebbek. A változtatásokkal szemben ez rezisztenciát eredményez. A biztonságot adó kötôdést az emberek önként vállalják, hozzá tartozik a megelégedettségükhöz, ezért ezt önkéntes helyi függésnek nevezhetjük. Létezik viszont egy nem önként vállalt helyi függớség is, a röghözkötés kényszerü formája. Az elköltözésnek, új lak- és munkahelyválasztásának számos társadalmi-gazdasági korlátja van. Többek között: lakáshiány, munkavállalási lehetôségek korlátozottsága, kulturális és életstílusbeli eltérések stb. Mindez különösen nehéz, ha valaki felfelé szeretne elmozdulni a településhierarchián. Az épített környezetet nem lehet átköltöztetni. Az ingatlanok és a bérleti díjak, valamint a megélhetési költségek térben eltérôek. Ugyanolyan nagyságú és minôségư ingatlan ára többszöröse a nagyvárosokban, mint a falvakban. Egy elmaradott térségben, egy hátrányos helyzetữ kistelepülésen egy ingatlan akár eladhatatlan is lehet. Ezeknek az ingatlanoknak az elhagyása - ezek piaca nélkül - veszteség a család és a nemzet számára egyaránt. A helyben eladott, hátrahagyott ingatlanból felszabaduló tốke nem elegendố arra, hogy máshol hasonló használati értékũ ingatlant vásároljanak rajta. Néhány esetben adminisztratív akadályai is vannak a költözésnek. Ez szinte természetes az egyes országok között, de például néhány 
„,túlfejlett” nagyvárosi körzetben adminisztratív eszközökkel is korlátozzák a beköltözést, és volt példa a területi emigráció drasztikusabb formában történỏ irányítására is (Szovjetunióban, Romániában, Bulgáriában). A legtöbb országban a szociális (tanácsi) lakások forgalma is nehézkes, települések közötti cseréje szinte megoldhatatlan.

Mobilitást korlátozó általános ok az információ hiánya. Természetes, hogy mindenki több információval rendelkezik a lakó-, munka-, telephelyén, mint az egyéb településeken kínálkozó lehetôségekrôl. Az informális csatornákon megszerezhetô információk döntéseket befolyásoló tényezốk lehetnek. Ezekhez az információkhoz más településen nem, vagy csak magas költségen lehet hozzájutni.

Cox és Mair (1988) az emberek helyi függổségének , ,hagyományos" és ,,modern” formáját különböztetik meg. A hagyományos társadalmi kötốdések, mint a faji, vallási, családi stb. bizonyos tér-idóbeli relációban erổs területi azonosšágtudatot eredményezhetnek. A magas fokú hagyományos helyi függôség nehézkessé teszi az emberek számára az elköltözést, viszont felfegyverzi ốket a helyi érdekekért folytatott harcra. Nagyon sok tradícionális társadalmi kapcsolat megszủnt vagy áru jellegưvé vált az állami beavatkozások következtében. A társadalmi szervezôdések és megítélések régi alapelveit újakkal helyettesítették. Ezek hozták létre a helyi függőség modern formáját. Az ezen alapuló azonosságtudat szigorúan alá van rendelve a karrieren, az anyagi fogyasztáson, a státuszon stb. keresztül mérhetổ egyéni újratermelés ideológiájának. Az egyéni karrier sikere, a családi boldogulás érdekében az emberek személyspecifikus kapcsolatokat építenek ki lakóhelyükön és ezeket nehéz késôbb, máshol újraszervezni. E kapcsolatok nélkül az egyén, a család nem tud hasonlóan sikeres életet élni. A modern helyi függőség is helyhez köti az embereket, habár korántsem olyan erôsen, mint a tradícionális kapcsolatok. A hagyományosból a modern azonosságtudatba való átmenet során a biztonságot adó közösségi kapcsolatok egy része elvész, és az emberek olyan világban találják magukat, amely érzéketlen a sajátosságokra, mindenütt azonos követelményeket támaszt velük szemben. Az értékrend univerzális intézményekbốl ered, a megújuló önkifejezôdésben a karrier, az anyagi fogyasztás, és a státusz játszik fontos szerepet, a hagyományos kisközösségi megítélés - a tradícionális értékrend - jelentőségét veszti.

\section{A helyi kormányzat}

A helyi kormányzat eo ipso helyileg függô. (Az egyértelmủen a központi kormányzattól függố tanácsok a központi kormányzatok ,,telephelyei” és nem valódi helyi kormányzatok.) A helyi függốség mértékét a helyi források aránya és a helyi demokrácia lehetôségei adják. Kedvezô esetben a vezetớk személye és a helyi politika a helyi választóktól függ. A település fejlôdése a polgáraik jövedelemtermổ képességén és érdekérvényesítési képességén múlik. A helyi tanácsok számára is gondot okozhat - a vállalatokhoz hasonlóan - az épített környezet immobil természete, nehéz konvertálhatósága, különösen, ha azok hitelekból épültek vagy tévesen elôrejelzett forrásokon alapultak. Ez problémákat okozhat, ha a gazdaság térbelileg átstruktúrálódik és az adóalapok csökkennek. A helyi anyagi függőség mérsékelhetổ a központi tâmogatások arányának növelésével, ami a költségvetés helyzetétốl teszi függớvé a helyi fejlesztéseket. A központi forrásokért való lobbyzás az elốzôek alapján felfogható úgy is, mint a helyi 
anyagi forrásoktól való függés lazítására tett törekvés. A külső források arányának növekedésével csökken ugyan a ,,helyi kiszolgáltatottság”, de nổ a nem kívánatos külsố függés.

\section{A vállalatok}

A klasszikus kapitalista vállalatok az input-jaikon és output-jaikon keresztül függnek szûkebb vagy tágabb környezetüktốl. A profitmaximalizálás ösztönzô ereje folytán fáradhatatlanul keresik a termelés többet hozó formáit. Ez sok esetben új közremúködốket és fogyasztókat jelenthet, $\mathrm{s}$ akár a termelés teljes áttelepítését is eredményezheti. Ezeknek a vállalatoknak viszonylag kicsi a helyi függôsége. Mégis vizsgálatok bizonyítják, hogy a vállalatok nehezen költöznek, sốt a bốvítéseket is inkább a már meglévố telephelyeken végzik. A már mứködố telephelyek mind az input-ok mind az output-ok tekintetében agglomeratív elônyöket kínálnak, és más helyi cégekkel a már meglévổ kapcsolatok azonnal rendelkezésre állnak. A költözés tetemes költségeitốl eltekintve, a meglévố helyi információk birtoklása és a más területekrôl beszerezhetố információk költségei és bizonytalansága is a költözés ellen hatnak.

Az állami és különösen a szocialista vállalatok helyi függôsége relatíve nagyobb, de ez nem par excellence gazdasági természetû. Ez a tulajdonforma és az érdekeltség eltéréséből fakad. A nagyobb lokális stabilitás megítélése ambivalens. Inkább a stabilitást képviselik mint a progressziót.

A tókés országokban az állami vállalatoknak nemcsak profitérdekeket kell szolgálniuk, hanem foglalkoztatási, ellátási, területpolitikai érdekeket is integrálniuk kell. A menedzsereknek a központi hatóságok által meghatározott célokat kell teljesíteniük, így a ,,központ” ítéletétôl jobban függnek, mint a helyi megítéléstôl. Ezek a vállalatok a kisebb konjunkturális ingadozásoknak kevésbé vannak kitéve, mint a magánvállakozások, ami pozitívan ítélhetổ meg, de a helyi közösség ráhatásának is kisebb az esélye, mint egy helyi közösségi vagy helyi magántulajdonú vállalkozás esetében.

A diktatórikus szocializmusban múködó állami vállalat termelési korlátait nem a gazdaság, hanem a paternalista pártállam és helytartóinak jóakarata jelöli ki. A vállalat helyi kötődése inkább a telepítési tényezôkre való érzéketlenségébôl, a gazdasági ôsztönzốk hiányából, mint a helyi szereplốk kreatív befolyásolásából fakad. A helyi hatást nem a dolgozók és a helyi lakosság demokratikus ellenốrzése jelenti, hanem a pártállam helyi szolgája gyakorolja egy nem létezô össznépi érdek nevében, amely a gyakorlatban a saját hatalom megtartását jelenti - akár a (helyi) társadalom ellenére is.

A szocialista vállalatoknak számos, nem a gazdasági funkciójukból eredố helyi kapcsolata van. A szocialista vállalatok és termelőszövetkezetek java része profiljától függetlenül nem az adókon keresztül, hanem közvetlenül vett részt a települések infrastrukturális fejlesztésében, a közszolgáltatások teljesítésében. Ez is hozzájárult ahhoz, hogy alaptevékenységük hatékonyságának megítélése torz képet mutatott. A társadalom mai elvárásai e tevékenységük felszámolására szorítja a gazdálkodó szervezeteket, de a jelenséget kiváltó ok - az önkormányzati eszközök elégtelensége - nem szünt meg. A szocialista vállalatok vezetối gyakran társadalmi funkcióik révén gyakoroltak befolyást a helyi döntéshozatalra. Nagy vállalat és viszonylag kis település esetén meghatározóvá válhat a vállalat érdeke. Ez különösen káros lehet a település 
számára, amikor hibás szabályozórendszereken alapuló torz érdekek érvényre juttatása irreverzibilis változásokat okoz a település életében. Vállalatok és önkormányzatok között a kölcsönös érdekeken alapuló együttmúködési formák kiépítése a járható út. Ezeknek a kapcsolatoknak ellenổrizhetố szerzôdéseken kell alapulniuk.

A közszolgáltatásokat végzố vállalatok általában nagy értékư, helyhez kötött vagyonnal rendelkeznek (erômművek, gázvezetékek stb.). Ezek helyi kötổése nagy. Egy részt vagyonuk nem mozgatható, másrészt a fogyasztók köre helyben adott. A nagy regionális és nemzeti hálózatok helyi függôsége kisebb, mint a helyi szervezeteké. A kisebb vállalatok (hálózati elemek) nemcsak hogy gyakran gazdaságosabban tudnak müködni, de helyi függốségük révén jobban tudnak alkalmazkodni a helyi igényekhez, mứködésük jobban összehangolható a helyi társadalom érdekeivel.

A pénzintézetek helyi függốsége az Egyesült Államokban igen magas. Biztosító társaságok, bankok pénzüket gyakran helyi ingatlanokba, vállalkozásokba fektetik. Az európai bankok egyre függetlenebbek. A szocialista országokban a takarékszövetkezetektól eltekintve nem beszélhetünk a pénzintézetek helyi függôségérôl. A pénzintézetek országos halózatok helyi fiókjai; önálló helyi bankok, biztosító társaságok nem léteznek. A magán-, kis- és középvállalkozások helyi függốsége viszonylag nagy. Ennek alapvetố oka a tulajdonos személyes helyhez kötổdésében van, amiról már a korábbiakban szóltam.

\section{Növekedés és/vagy fejlödés}

Néhány polgári közgazdász, valamint az ortodox marxisták körében még ma is széles körben elfogadott nézet, hogy elsôsorban a gazdasági növekedésre kell koncentrálni, és az így megtermelt anyagi alapok teremtik meg a lehetổséget a minôségi tényezốk javitásához. E tétel gyakorlati alkalmazása során megfeledkeznek arról, hogy az oly sokszor emlegetett ,,torta" növelése, mely az elosztás alapját képezi, többféleképen is megoldható, és ha - csak a mennyiségre figyelve - nem megfelelổ eszközöket alkalmazunk, a felhasznált források kárba veszhetnek, a remélt eredmény elmarad.

Ma már a közgazdászok többsége is különbséget tesz a növekedés és a fejlôdés között. (Arndt 1987; Flammang 1979; Friedman 1986; Schaffer 1988; Seers 1977; és mások.) A fejlôdés nem csupán mennyiségi fogalom, hanem egyre inkább minốségi ideává, komplex, emberi, társadalmi jelenséggé válịk. A fejlốdés a tágabb fogalom, ami magában foglal(hat)ja a növekedést, amely természeténél fogva mennyiségi kategória. Hosszú távon inkább a növekedés a fejlódés függvénye, mint fordítva. A fejlổést általában növekedés is kíséri, de fordítva ez nem feltétlen igaz. A fejlódés megvalósulhat kevesebb gazdasági aktivitás mellett, azaz növekedés nélkül is. A növekedés csak akkor jár fejlődéssel, ha az egyben megváltoztatja a társadalmi-gazdasági rendszer szerkezetét is. Egyre inkább a minổségi változások válnak fontosabbá és a mennyiségi változások veszítenek relatív jelentôségükbôl. Flammang (1979) is azt hangsúlyozta, hogy a fejlổés strukturális változás, amely alatt valami mást és nem többet kell érteni. ,,A fejlódésnek ez az új fogalma társadalmi átalakulási folyamatot kíván meg, amely során a gazdasági, a kulturális, a politikai, az ökológiai és más tênyezốk újszerủen hatnak egymásra." (Stöhr 1986, 66.) 
John Friedman $(1972,86$.), felhasználva Kuhn, Kuznetz és mások elméleteit, rámutat arra, hogy a fejlődés ,,... szakaszos kumulatív folyamat, elemi innovációk sorozataként következik be, amelyek innovatív klaszterekbe és végezetül nagyléptékú innovációs rendszerekbe szervezổnek. Az innováció technikai és intézményi jellegư lehet. Az utóbbi esetben társadalmi, gazdasági, politikai és kulturális kategóriáknak célszerú alárendelni."

Mostanában új értékek kezdenek nagyobb szerepet kapni, és újra felfedezzük a tradícionális emberi alapértékeket. Egyre több olyan, ,puha" ismérve van a fejlôdésnek mint az életminôség, a környezet minổsége, a kulturális örökség megổrzése, az önigazgatás, a politikai függetlenség stb. A korábbi gazdasági fejlődés alternatívája, pontosabban új értékekkel való kiegészítése új politikai, szocio-kulturális és gazdasági célokat tételez fel. Ezek megfogalmazása és végrehajtása csak részben képzelhetố el nemzeti szinten, nagy szerep hárul a regionális és helyi közösségekre.

A fejlódést a helyi társadalom számára is a helyi folyamatok szerves folytatásaként jelentkezó strukturális változások jelentik. A strukturális változás megjelenhet a termelési tényezốk változásában, a meglevố erőforrások jobb kihasználásában, az intézményi rendszer átalakulásában és a lakosság értékrendjének és attitűdjének változásában egyaránt. A helyi társadalom szempontjából a fejlốdés a lehetôségek bớvülését jelenti. Az egyén egyre több ,fajta” munkahely, lakóhely, iskola stb. közül választhat, illetve egy adott lehetőséget a helyi társadalom egyre szélesebb rétege érhet el. A helyi fejlódés társadalmi megítéléskor hasznosítható a Pareto-féle törvény adaptációja. Oberle, Stowers és Darby $(1974,62$. ) szerint , ,... a fejlôdés olyan folyamatként határozható meg, amely során egy adott körzet növekvó számú tagja hoz és hajt végre társadalmilag helyes döntéseket, amelyek valószínú következménye emberek életlehetôségeinek növekedése anélkül, hogy mások életesélyeit csökkentenék."

Hazai fejlö́désünk szempontjából is alapvetônek tartom azon tétel elfogadását, miszerint, ha egy ember, egy helyi közösség, egy réteg stb. anélkül fejlốdik, hogy mások rosszabb helyzetbe kerülnének, akkor az nemzeti szinten is fejlódést jelent. Az egyes ember, egy helyi vagy munkahelyi közösség számára nem elfogadható az életfeltételeik javításával szemben sokat hangoztatott érv, hogy mások életszínvonala alacsonyabb. Ma már egyértelmü, hogy a kelet-európai kommunista pártok egalitárius politikája a teljesítménynövelés, a haladás ellen volt. A ,,kis kunyhó és nagy palota" példája úgy is értelmezhetổ, hogy amíg a kis kunyhó lakójának nincs tudomása arról, hogy másként is élhetne, nem is keresi annak módjăt teljesítménye növelésével vagy a rendszer megvăltoztatásával.

\section{A (gazdasági) fejlódés lehetôsége}

A világ minden nemzetének, regionális és helyi közösségének általános célja saját jólétének fokozása. Ennek módja a) saját erôforrásainak a ,,helyi” közösség érdekében történó mind teljesebb kihasználása és b) a külsổ források mind nagyobb arányú megnyerése. Ennek eléréséhez a korábbi fejlesztési politikát és gyakorlatot ki kell egészíteni a helyi gazdaságfejlesztéssel ${ }^{6}$, amely képes bármely közösség versenyképességét javítani.

a) Adott idốben a különféle források piaci megítélése a nemzetközi (nemzeti) fốbb tendenciáknak megfelelóen alakul. Azaz a helyi erôforrások egy része, kedvezốtlen esetben nagyobbik 
hányada, a kereslethiány következtében kihasználatlanul maradhat. A helyi közösség szempontjából ez akár , végzetes” is lehet. A helyi közösség, illetve választott vezetôiik feladata, hogy feltárják az alternatív hasznosítási lehetôségeket, vagy a tulajdonviszonyok vagy az intézményi feltételek változtatásával fenntartsák a termelést (a munkahelyeket), menedzseljék a helyi érdekeket.

b) Ma már kevés, ha egy közösség általános feltételeket kínál a külsố források (munkaerố, tốke) vonzására. Ezek esetleg szükséges, minimális elôfeltételek lehetnek (jogállamiság, megfelelố szintứ munkakultúra, infrastruktúra stb.). Egyre inkább az a közösség képes külsổ tốkét, szellemi potenciảlt helybe vonzani, amely kedvezốbb megtérülési lehetôségeket tud biztosítani és a munkaerổnek jobb életlehetốséget kínál (munkahelyi biztonság, jó kereseti lehetốség, jó lakáshelyzet, megfelelổ ellátás, egészséges környezet stb. ). Ezeknek a többi lokalitáshoz viszonyított szintje a lényeges. Minél magasabb szintữ szolgáltatásokat kínál, illetve minél egyedibb adottságokkal rendelkezik egy adott település, régió, annál inkább képes vonzását kiterjeszteni. Amennyiben sikerül külsố forrásokra szert tennie, a helyi haszon mértéke a helyi közösség érdekérvényesítổ képességén múlik.

\section{Egy tércentrikus irányítási (tervezési) rendszer vázlata}

A gazdasági alapokon nyugvó, a politika által befolyásolt irányítási rendszereknek három egymásra kölcsönösen ható alrendszere különíthetô el: a programalkotó (tervezési), a közvetítô (szabályozási) és az intézményi és szervezeti alrendszerek. Ezeknek tendenciaszerũen meg kell felelniük egymásnak, azaz az eltérổ központi politikához más eszközrendszer társul és más intézményi struktúrát kíván meg. Az irányítási rendszer múködése vertikális és horizontális kapcsolatokra épül. A vertikális és horizontális kapcsolatok aránya a centralizáltság mértékétớl, az állam és a többi szint súlyától, szerepétốl és az egymáshoz való viszonyuktól függ. Ha nagyobb szerepet kapnak a piaci viszonyok, nỏ a vállalti és területi önállóság, akkor szinte automatikusan veszít jelentôségéból az ágazati irányítás, más lesz a vertikális kapcsolatok jellege, mód adódik közvetlen helyi érdekkapcsolatok kialakítására és szükségessé válik egy decentralizáltabb irányítási modell bevezetése. Egy decentralizált irányítási rendszerben egyre fontosabb szerepet kap a területi irányítás: a területi politika és tervezés. Egy tércentrikus irányítási/tervezési modellben egyformán mérlegelốdnek a különbözó gazdasági tevékenységek, a fogyasztás, az életminốség stb. Ebben az esetben a tervezés több, mint puszta eszköz. A célok felvázolása, azok döntést igénylő rangsorolása, a stratégiák és taktikák kialakítása, az eszközök megválasztása olyan komplex tevékenység, amelyben a tudományos megalapozás, a szükséges érdẻkegyeztetés, célok és eszközök szerves egységet alkotnak. Felfogásom szerint a területi politika és tervezés, és a végrehajtás ma már nem elválasztható. A tervezés, a területi tervezés a területi folyamatok megismerése és tudatos alakítása során szükségszerúen érinti az irányítási rendszer szabályozási és intézményi alrendszereit is, így kiemelt szerepet kell hogy kapjon az irányítási rendszeren belül.

Mik lehetnek a tércentrikus irányítási/tervezési modell alapelvei?

a) Az alapvetố rendezó elv a területileg elkülönült népesség. A tervezés alapegységei a területi (közigazgatási) egységek. A helyi, a regionális tervezés során az egyes területi egységek kap- 
csolatba lépnek egymással. Közösen tervezhetnek programokat, illetve koordinálhatják tevékenységüket. Ez számos területen rendszeres a települések és az ốket befogadó régiók között, és közösen belátott érdekazonosságon alapulhat az egyes települések viszonyában. A nagyobb területi egység és a települések kapcsolata sem függốségi. Ha sikerül a vertikális tagozódás elemei között megtalálni a helyes munkamegosztást, akkor ez a tervezési kapcsolat is inkább horizontálisnak tekinthetô. A települések szövetkezhetnek vagy társulhatnak a közös tervezésre, tervezô szervezet létrehozására és fenntartására, valamint a közös célok megvalósítására egyaránt.

b) Az állam többé nem a legfổbb determinátor. A nemzeti szintû́ program javarészt a települések, régiók terveibốl áll össze. A központi tervezés fô feladata a rendszer egyensúlyának fenntartása. Erre az egyensúlyozó szerepre azért van szükség, mert a területi alrendszerek fejlesztései összefüggnek, másrészt a politikai irányok integrációját a nemzet kell hogy képviselje. Egy adott területi politikába nyilván nem kell beavatkozni, ha annak meghatározása során a külsố hatásokkal számoltak, a különbözổ érdekegyeztetések megtörténtek. Akkor kell csak beavatkozni, ha a szóbanforgó régió és a nemzet egészének fejlôdése ennek ellenére ellentétbe kerül.

A központi szabályozás normatív módon hat a helyi irányításra, tervezésre. Vannak feladatok, amelyeket teljes önállósággal terveznek, vannak, amelyeket végrehajtási önállósággal és végrehajtási kötelezettséggel valamint olyanok, melyeket végrehajtási kötelezettséggel határoznak meg. ${ }^{7}$

c) A közvetlen beavatkozások csak esetiek. Egyrészt szükségessé válhat direkt központi beavatkozás például országos jelentôségứ programok megvalósítása érdekében vagy természeti katasztrófákat követôen, másrészt ezek a viszonylag önálló területi egységek konfliktusainak feloldásában segíthetnek. Célszerũ, ha a központi hatóságok, állami szervek is egyezségen alapuló, jogi szerzôdések által garantált módon vesznek részt a központilag preferált kérdések támogatásában.

Ebben a modellben a területi egységek kis társadalmakként foghatók fel. A társadalmi tevékenységek tervezése kerül elốtérbe, ami ellentmond az ágazatcentrikus gondolati struktúrának. A vertikális ágazati struktúra helyébe a nagyobb önállósággal bíró területi egységek horizontál is kapcsolatai, kölcsönös egymásrautaltsága kerül. Automatikusan felértékelő̉dnek a helyi adottságok és lehetốségek. A területi tervek egyik fổ funkcója a koordináció, az érdekegyeztetés. Ebben a modellben a tér nem passzív tényezôje a rendszernek, hanem aktívan hat a társadalmi tevékenységekre.

A tervezô és a megrendelố viszonya az egyszeri megrendelés és elfogadás helyett — dialógus. A tervezés is politizálódik, és ebben a területi mozgalmak fontos szerepet kaphatnak. A tervezésen belül a tárgyalások, egyeztetések, alkuk szerepe nổ. A mennyiségi mutatók jelentốsége csökken, a minốségieké nô. A belsổ folyamatok tervezése erốsödik. A tervezés nagyobb szerepet kap a helyi társadalmak önszervezésében.

Nem szükséges a jövedelmek nagymérvũ központosítása és újraosztása sem. A területi szintek önállósága saját hatáskört, saját bevételeket és ennek következményeként saját feladatteljesítést jelent. A területi, a helyi akaratképzési mechanizmus sem politikamentes. A helyi tervezés kapcsán hozott döntések a helyi politika képzésének részei, és ugyanez vonatkozik a helyi igazgatásra is. A források allokálása, beruházások rangsorolása értékválasztáson alapul! A tervezés politikai karaktere ott érhetố tetten, hogy mindig konkrét érdekek alapján választanak 
a lehetséges alternatívák közül. Ugyanakkor ezek a helyi döntések nem pártpolitikai döntések. A pártok a generális kérdésekben foglalnak állást, a helyi politikában a helyi erốviszonyokat tükrözó konszenzus alapján operatív kérdésekben kell döntést hozni.

A tér ebben a rendszerben elkülönít, tömöríti, artikulálhatóvá teszi a területi érdekeket, ugyanakkor ez fel is oldódik, hiszen az elkülönülổ területi egységek érdeke, hogy keressék a kooperációt, az együttmúködést, amelyet döntôen horizontális kapcsolatokban találnak meg.

Mivel a tér, a helyi társadalom a fỗ rendezổ elv és nem az ágazatok speciális belsố törvényszerû́ségei, így a korábbi rendszerben nem , versenyezhetố alternatívák" kerülhetnek egymás mellé. Nagyobb hangsúlyt kapnak a helyi adottságok, a népesség konkrét igényei és munkavállalási lehetốségei. Ez módot ad a társadalmi munkamegosztásba való harmonikus beilleszkedésre is. Ebben a rendszerben közelebb kerülnek a célok az azokat megvalósító emberekhez, továbbá mód nyílik a megvalósulás közvetlen ellenổrésére és a gyors beavatkozásra egyaránt. Ebben a modellben az árutermelés sem csak kizárólag ágazati keretek között folyik, hanem legalább ilyen fontos kerete a hely, a lokalitás társadalma. A központi költségvetés rovására erôsödnie kell a területi és helyi finanszírozó képességnek. A helyi fejlesztések kiinduló pontja nemcsak az árutermelố szektor fejlesztési igénye, hanem éppúgy a helyi társadalmak fejlổési lehetôségei is.

A regionális mozgalmak nagyobb politikai autonómiát, nagyobb lehetôséget kívánnak a kulturális önkifejezésre. Ez területi politizálást is jelent. A korábbi egységes nemzeti pártok mellett területi pártok, területi politizálás is megjelenik. Illetve célszerứ ha az országos pártok helyi szervezetei aktuális területi, helyi célokat is felvesznek programjukba. A területi tervezốknek kapcsolatban kell lenniük a területi mozgalmak vezetôivel, azzal a helyi gazdasági kulturális elittel, amelyeknek tagjai befolyást gyakorolnak a helyi társadalom véleményére és vállalni tudják a helyi érdekek artikulálását. A regionális mozgalmak nem osztály- vagy rétegpolitizálást jelentenek. A közös területi-kulturális-gazdasági érdek azonosságot teremthet egy sor kérdésben. ${ }^{8}$ Ebben az esetben az egyént nem mint a nemzethez tartozót, hanem mint az adott régió, település lakóját motiválják érdekei. Ebben az esetben a területi tervezônek nem a kívülrốl érkezổ feladatokat, eszközöket kell elsốsorban allokálni, hanem a fejlổdés belsổ erôit kell feltárni, a helyi társadalom igényeinek kell megfelelnie.

\section{Összegzés helyett}

Akkor lenne szabad a fejlett Nyugat által diktált modernizációs fejlốdéskurzust fenntartás nélkül követnünk, ha valami isteni csoda (ma még fel nem ismert objektív trend) következtében sikerülne annyira felzárkóznunk hozzájuk, hogy mi is termelổivé, így elsốdleges haszonélvezচivé válhatnánk e fejlổdésstratégiáknak. Sajnos erre nem sok esélyünk van. Esetünkben, a , külsổ modernizáció" a szerves fejlốdés hiánypótlását jelenti, amit nem tekinthetünk ideális állapotnak.

Magyarországon nem az ốsi, kulturális-nemzeti vívmányaink mumifikálására van szükség, hanem olyan fejlổési pálya megtalálására, mely mindenkinek segít megőrizni a saját, a közösségi és nemzeti identitását és fenntartja a környezeti egyensúlyt. A tradícionalizmus alkalmas lehetne a nemzeti kultúra megốrzésére, de egy más (talán posztmodern) alapállásból, úgy élhet- 
jük meg a fejlổdését, hogy képesek vagyunk befogadni a kultúrák sokféleségének értékeit anélkül, hogy áldozataivá válnánk a , kultúrpolitikai imperializmusnak” és preferenciarendszerünk internacionalizálódna. Balgaság lenne általában elvetnünk a modernizációt, megtagadni magunktól a jóléti társadalom eredményeit. Az egy doktrínára épülô, központi fejlesztési politikák helyébe lépô, alulról építkezõ, a másságot toleráló, a természettel harmonikus kapcsolatba lépố fejlesztési stratégia nem feltétlen jelent ,,sajátos magyar utat”.

Ma már több - a gyakorlatban is igazolódott - elmélet van, amely méltányosabb, kiegyensúlyozottabb területi fejlôdést ígér (helyi/közösségi gazdaságfejlesztés, belsơ, alulról kezdeményezett fejlesztés self-reliant fejlôdés stb.). Ezeknek az alternatív fejlesztési elképzeléseknek közös, most kristályosodó alapállása a posztmodernizmus ${ }^{9}$. Az alternatív fejlesztési stratégiák közös kiinduló pontja a tôke logikáján alapuló modernizáció hegemóniájának az elutasítása. Ezzel a tér újra nagyobb jelentổséget kap a társadalmi-gazdasági kapcsolatokban. Egyes határok veszítenek jelentôségükbôl, míg etnikai, kulturális és mindennapi terünk újra fontosabbá válik. A vasfüggöny ideig-óráig alkalmas volt arra, hogy jót és rosszat egyaránt feltartóztasson, a Nyugat által termelt és irányított fejlổdéstốl megvédjen. Ma arra van szükség, hogy az egyének és közösségeik képesek legyenek a számukra hátrányos hatások ellen védekezni, ugyanakkor eséllyel induljanak az elổnyök megszerzéséért. Ezeréves történelmünk során elöször meg kellene próbálni alulról (is) építkezve új fejlôdéskurzust létrehozni.

A helyben, regionális szinten kezdeményezett, irányított fejlesztés nagyobb eséllyel képes feltárni a sajátos erớforrásokat, azokat hatékonyabban tudja felhasználni a helyi lakosság valós érdekeinek megfelelôen és képes megtalálni és betölteni azokat a gazdasági réseket, amelyek kiesnek a makro- és mikroökonómia látóköréből. Új munkahelyek generálásával enyhíti a regionális és nemzeti foglalkoztatási gondokat. Csökkenti a központi költségvetés terheit, ezzel mérséklỏdhetnek a központi elvonások, ami javítja a megtermelt jövedelmek felhasználásának hatékonyságát.

A most kialakuló jogi keretek (remélhetôen) lehetôséget biztosítanak arra, hogy az állampolgárok politikai pártjai, érdekvédelmi szervezetei, vallási és egyéb közösségei által ellenôrzött önkormányzatok aktívan kézbe vehessék a regionális és helyi közösségek sorsának alakítását. Ez nem biztos, hogy a hagyományos értelemben véve kiegyensúlyozottabb regionális fejlổdést eredményez, de bizonyosan ,,más" és társadalmilag igazságosabb fejlổésszakasz kezdetét jelenti.

\section{IRODALOM}

Arndt, H. W. (1987) Economic development: The History of an Idea, University Press, Chicago.

Bartke I. (1989) A társadalom és a gazdaság területi szerkezetének alapvonásai, Akadémia Kiadó, Budapest.

Bassand, M.-Brugger, E. A. et. al. (szerk.) (1986) Self-reliant Development in Europe: Theory, Problems, Actions, Aldershot, Gower P. C.

Cox, K. R. és Mair, A. (1988) Locality and Community in the Politics of Local Economic Development. Annals of the Association of the American Geographers, 78 (2).

Faragó L. (1990) A helyi gazdaságfejlesztés elmélete, Gazdasági Fórum, 2.

Flammang, R. A. (1979) Economic Growth and Economic Development; Counterparts or Competitors. Economic Development and Cultural Change, 28 (1) Oct.

Friedmann, J. (1972) A General Theory of Polarized Development, In: Hansen, N. M. (szerk.) Growth Centers in Regional Economic Development, New York, The Free Press. 
Friedmann, J. (1986) Regional Development in Industrialized Countries: Endogenous or Self-Reliant, In: Bassand, M.; Brugger, E. A., et. al. (szerk.) i. m.

Greenbie, B. (1976) Design for Diversity, Amsterdam, Elsevier.

Hall, E. (1966) The Hidden Dimension, New York, Doubleday \& Company.

Körösényi A. (1989) Liberális vagy konzervativ korszakváltás, Magvetố Kiadó; Budapest.

Oberle, W. H.; Stowers, K. R. és Darby, J. P. (1974) A Definiton of Development, Journal of Community Development Saciety, Vol. 5.

Schaffer, R. (1988) Community Economics. Economic Structure and Change in Smaller Communities, Ames, Iowa State Univ. Press.

Seers, D. (1977) The New Meaning of Development, International Development Review, 3.

Stöhr, W. (1986) Changing External Conditions and a Paradigm Shift in Regional Development Strategies? In: Bassand, M. et. al. (szerk.) i. m.

Verebélyi I. (1987) A tanácsi önkormányzat, Közgazdasági és Jogi Kiadó, Budapest.

\section{JEGYZET}

" Igen izgalmas, elgondolkodtató kérdés, hogy a Kelet-Európában jelenleg végbemenố folyamatok a ,nyugat" - megújult formájú - térnyerését jelentik-e, vagy van-e reális esélyünk sajátos, önálló fejlödésre.

${ }^{2}$ Több országban radikális közigazgatási reformra került sor, amely során a helyi közigazgatási, népképviseleti szerveket összevonták. Pl. Svédországban az 1974-ben végrehajtott közigazgatási reform eredményeként mára csak 284 tanács maradt. A választott tanácstagok száma 1950-rơl 1974-re egynegyedére csökkent.

${ }^{3} \mathrm{PI}$. az USA-ban 1970 óta a kisvárosok és a falusias térségek gyorsabban növekszenek, mint a nagyvárosok. Csökken a különbség a munkavégzés jellegében, az infrastruktuális ellátottságban, az életmódban stb.

4 Hall egy korábbi tanulmányában a proxemics-t úgy határozta meg, mint ami megmutatja, hogy az ember hogyan struktúrálja a mikro-körzetét. Azoknak a ,távolságok"'nak a jelölésére használta e fogalmat, amelyek a mindennapi tranzakciók során alakulnak ki, valamint a lakóterek, illetve a települések elrendezésében nyilvánulnak meg. Késóbbi könyvében (1966 p. 1.) azt írja, hogy a proxemics fogalmat azon elmélet és megfigyelések számára alkotta, amelyek az ember térhasználatát mint kulturális jelenséget vizsgálják.

s Példa erre, amikor a helyi lakosság harcol a munkahelyek bezárása vagy a tớkekivonás ellen, vagy amikor egy cég szolgálati lakással, szerzớdésekkel próbálja lekötni a munkaerốt stb. Egyes szereplók, akik felismerik a túlzott helyi kötốdés árnyoldalait, megpróbálják azt lazítani. Ez a törekvés épületek bérlése, multilokális telepítés, helyi kooperáció kiváltása stb. segítségével sikeres lehet.

- A helyi gazdaságfejlesztésról bớvebben lásd: Faragó L. (1990).

7 A központi szabályozás elớrhatja, hogy hány gyerek esetében kell általános iskolának müködnie egy településen, de hogy ezt milyen módon oldják meg, az helyi kérdés. Vannak szabadon választott feladatok, pl. falumúzeum létesítése. (Ezek még a normatív szabályozás alá sem esnek.)

${ }^{8}$ Egy utca közmưvesítése éppen úgy érdeke az ott lakó vállalati menedzsernek, mint a munkásnak. Egy nukleáris beruházás meghiusítása érdeke lehet a térség összes lakójának osztály, réteg, vallási felekezethez való tartozástól vagy pártállástól függetlenül.

- Ma még nehéz pontosan meghatározni ennek az alternatív álláspontnak az érdemi tartalmát. E világkép - a modernizáció korábbi kritikáitól eltéróen - létét és elnevezését azzal is igazolja, hogy nemcsak a modernség válságával, hanem a válaszadással is foglalkozik. Az egoizmus helyébe a szolidaritást, a hedonizmussal szembe a mértékletességet, a racionalizmus mellé az intuitív, meditatív megismerést helyezi. A további fejlódés lehetôségét a specializáció, a komplexitás fokozása, a termeló egységek növelése helyett a differenciálódásban, a sokszínüségben látja. Nem ismer el hegemón doktrínát, totalizáló ideológiát. A tágan értelmezett nyelvek, kultúrák sokaságábớl kíván új enớt meríteni. 


\section{SOME ASPECTS OF THE CHANGING MODEL OF CONTROL SYSTEM}

\section{LÁSZLÓ FARAGÓ}

According to the author, during the three decades following the Second World War, the highly successful control model of the developed capitalist countries shows several similarities to the socialist experiment which failed. Central control and planning became the bureaucratic means of realizing central objectives and direct intervention into market mechanisms. This model was also built up of the basic elements of the economy and it also focused on economic development. This stystem gave preferences to large, productive organizations. National economy was considered to be the most relevant level of planning, and state intervention was a generally accepted doctrine. The main purpose was, everywhere, to develop a uniform industrial society, and thus specific regional interests could not be taken into account. By the 1980s, as a result of the new industral revolution, this "success model" of modernization lost some of its driving force, and the developed Western states, parallel with Central-Eastern Europe, are looking for the new structure which could/would give new impetus to development.

With the analysis of the spatio-cultural existence of people, and of the local dependencies, the author intends to support the idea, that the tendencies of decentralization which started all over the world, and the increased role of small communities, the locality, have very deep roots. People try to find their safety in the center of their spatial relations, in their everyday Lebensraum. The importance of those small territories, where people can communicate face to face, where everybody can react to, and if necessary, can influence the processes, is continuously growing. Developments are increasingly based on regional identity formed by the actors of the region and rooted in local culture.

Actors of everyday life are dependent on regionally reproduced socio-economic conditions. The traditional and modern forms of local dependencies decrease the willingness of people and organizations to change and mobility and, at the same time, arm them tocarry out activities required to enforce their own interests.

Development is a kind of structural change, when economic, cultural, political, ecological and other factors influence each other in a new way, thus it cannot be identified with quantitative development. Wording and executing the aims related to the "soft" characteristics of development (quality of life, preservation of cultural heritage, self-government, political independence, quality of environment, etc.) can only partly be imagined on national level, and the different regions and settlements have significant role in them, too.

Requirements of local economic development (exploring specific conditions and using them to the greatest excent in local interests, etc.) also necessitate a model which is constructed from the bottom to the top.

The author descirbes the theoretical outlines of a regional-centric control/planning model, where the different economic activities, consumption, quality of life, etc. are equally judged and considered, and which can be reconciliated with the political and economic changes and does not interfere with the model of local governments to be introduced soon, either. In this 
model, the state is not the most important determining factor any more. The regionally separated population is the basic principle of organization/arrangement. The space separates, makes the regional interests more articulate and solid, but at the same time it is alsodissolved, because it is the basic interest of separate regional/spatial units to find the ways of cooperation, which - in the majority of cases - can be found in horizontal relations. Based on mutually acknowledged similarity of interests, the different regional units can plan common programs and/or coordinate their acitivities. Central control has normative influence on local control and planning. Direct interventions are only accidental. It is very useful, if the central authorities and state organizatons participate in the support of issues preferred on the basis of agreements and according to the guarantees of legal contracts. Planning is becoming political, and regional movements have increasing role in them.

Finally, the author draws the conclusion, that Hungary should not follow mechanically the course of modern development dictated by the West mechanically, but we do not need the preservation of our ancient, cultural achievements either. What we really need is a path of development, which helps everybody in preserving his/her own, communal and national identity and sustains the environmental balance. We should choose the course of development, which would facilitate us to accept and receive the values of the diversity of cultures without becoming the victims of "the imperialism of cultural policy" and without making our system of preferences totally international. The development strategy which is built up from the bottom to the top, tolerates differences and is in harmony with nature - this would substitute the development policies based on one doctrine and central development policy - does not necessarily mean a "specific Hungarian way". At present, there are several development theories/strategies which promise more equitable and more balanced regional development, and which have already been and are still applied successfully in several countries. During more than one thousand years of her history, Hungary should try, for the first time, to develop a new course of development built up from the bottom to the top, and this way we could go by the latest trends of development.

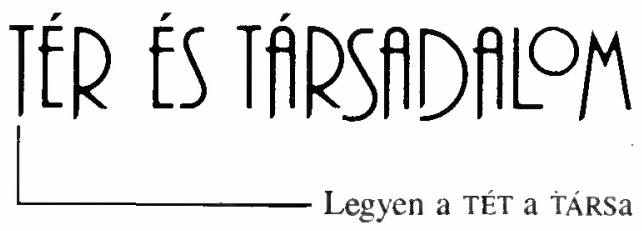




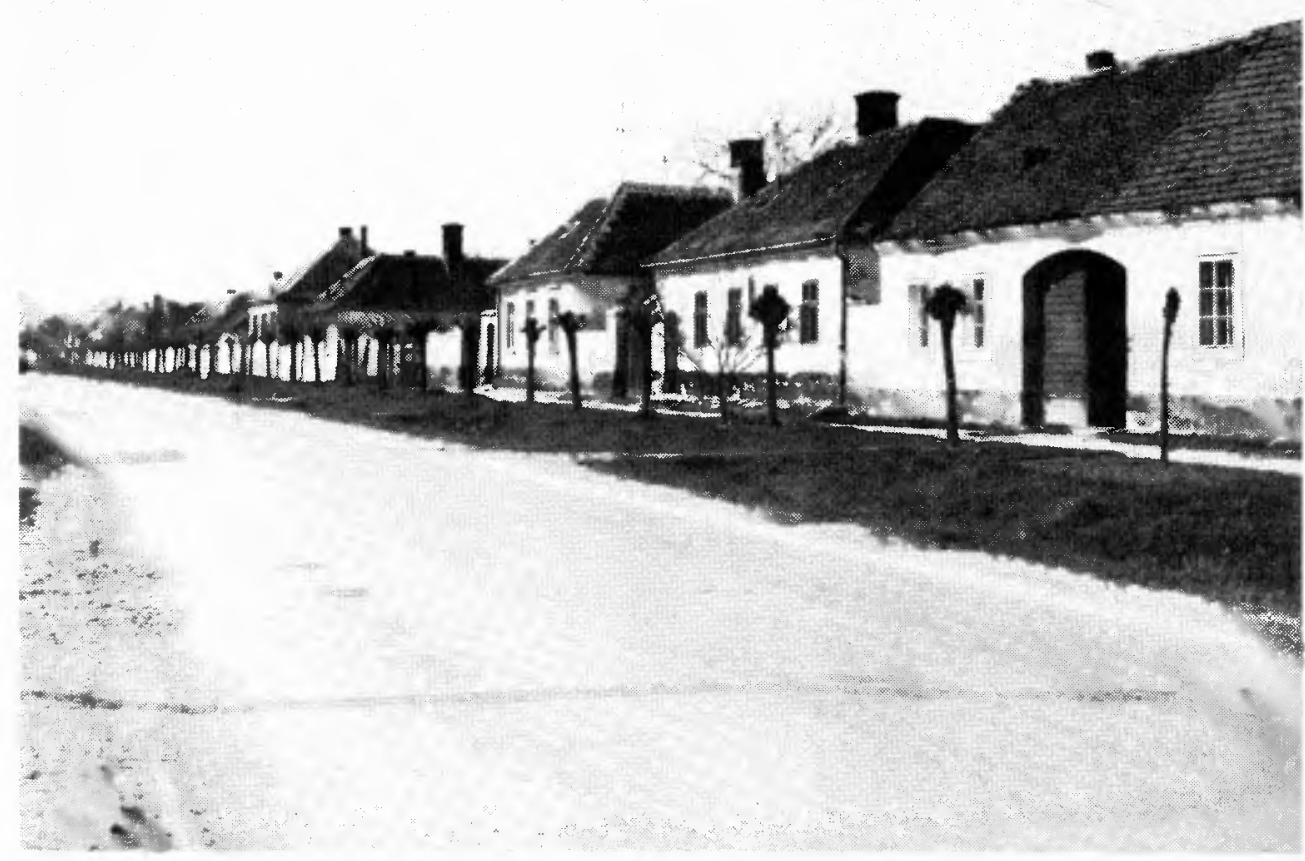

Az országhatár közelsége korról-korra, helyról-helyre eltéró módon befolyásolta az ottélok helyzetét. A szomszédság jelentett allandó fenyegetést, de jelentette az áruk, eszmék, ismeretek közeli, bö forrását is. A határmentiség az elmúlt évtizedekben a periféria szinonímája lett, nem ok nélkül. Hátrányos helyzetũ területeink zöme egyben határmenti fekvésü is. Képeinken azonban belbukkannak a valamikori elönyök emlékei is. Szerencsés esetben az országhatár közelsége, az ebból fakadó elönyök a polgärosodás elömozdítói is voltak; ez tükrözödik a Vas megyei faluképen. Az utca vonalával párhuzamos tengelyü házak, a zárt kerítések, nagykapuk már-már kisvárosi utcaképet eredményeznek.

A megviselt tetók, a hiányzó csatornák, a régfestett lábazatok viszont az elmúlt évek , zavarainól" árulkodnak. 